\title{
Improvement of Students' Ability With Mathematics Learning Innovation Based on Handphone Technology
}

\author{
M. Taufik Qurohman'1, Muchamad Sobri Sungkar², Taufiq Abidin³ \\ ${ }^{1}$ Politeknik Harapan Bangsa Bersama, Tegal, Indonesia \\ Email: taufikqurohman87@gmail.com \\ ${ }^{2}$ Politeknik Harapan Bangsa Bersama, Tegal, Indonesia \\ ${ }^{3}$ Politeknik Harapan Bangsa Bersama, Tegal, Indonesia
}

\begin{abstract}
Assisted learning model of Handphone-Based Mathematics Learning Devices is expected to be able to provide solutions to students to improve their attractiveness and problem solving abilities. The purpose of this study is to optimize the learning model of the Handphone-Based Mathematics Learning Device. In the ongoing research process, the following conclusions are obtained: (1) Using the 3-D development model (modification of 4-D) results in an applied mathematics learning device 2 with the help of the Handphone Application, where the device consists of RPS, RPP and Handphone Application. Learning devices that go through the validation process and are declared valid by experts in their fields, the mathematics learning tools developed with the Handphone Application in this study are valid, (2) The use of the Handphone Application in the experimental class is better than its ability in problem solving skills compared to the learning process in class with conventional learning, (3) Using a 3-D development model (a modification of 4-D) produces an applied mathematics learning device 2 with the help of an Android Application, where the device consists of RPS, RPP and Android Application. Innovation of learning devices has been through the validation process and declared valid by people who are experts / experts in their field, then the mathematics learning devices developed with Android applications in this study are valid, practical, and effective
\end{abstract}

Keywords: Achievement Improvement, Mathematics Learning, Mobile

\section{Introduction}

The development of technology in the field of education and the use of technology in the learning process is very influential on the learning outcomes of students / students, the renewal must be able to offset the development of the industrial revolution era 4.0. And the hope of these technologies can provide benefits to the world of education, and useful in the world of education [1]-[3].
Lecturers are expected to facilitate the process in groups in the learning process, not only directly provide answers [4]. Learning methods are very helpful in influencing the effectiveness of learning which is reflected by increased achievement. This is certainly expected to be the beginning of the formation of a good and integrated learning system. With current technological developments that really need a good quality improvement. Especially at this time when it has entered the era of the revolution 4.0 which has a comparison that is in harmony with technological developments. 
Learning innovation is learning innovation in which students compile their own knowledge, and develop independence [5]. Innovation of the Handphone-Based Mathematics Learning Tool is one of the learning models that has a characteristic that is always initiated and problem-centered. In the learning process students can work in small groups and must identify what they have understood and always try to solve problems. In this research, the learning process is carried out to analyze the level of understanding and problem solving of students by applying the Handphone -Based Mathematics Learning Tool as a model. So that the research carried out is expected to provide positive changes to changes in student achievement levels in applied mathematics courses 2 .

\section{Research Methods}

This research is classified in the development category where applied mathematics learning tools are developed with the help of experts. And these tools are the Learning Plan of semester (RPS), Learning Implementation Plan (RPP), and the Handphone Application. The device innovations in this learning process are to produce designs and then revise them by experts and data from the device trials. Activities undertaken for data analysis include validating the learning tools and trials as follows:

\section{a. Device validation}

Validation carried out provides several things that must be considered, including suggestions and criticisms to revise the equipment obtained draft III. Draft II is categorized as practical after going through the practical test phase. Draft III was then field-tested to obtain an effective tool. After passing the effective test, a valid, practical and effective final device is obtained.

b. Practicality Test

The device is said to be practically obtained from the lecturer observation data and student response questionnaire. Handphone -based learning management observation sheet on Applied Mathematics material 2. Observations were made during the learning process by 2 observers. The questionnaire given to students is intended to measure the achievement of learning by students in applied mathematics courses 2 with a Handphone -based learning model.

c. Effectiveness Test

The device trials provide clarity and input to the learning process in the form of recording all responses of students, lecturers, and observers, as well as tests of learning outcomes to revise or perfect devices.

The procedure of developing this device uses the steps of the Four-D development model which in this study was simplified into three stages (3D), which include defining, designing, and developing. The population in this study consisted of 15 classes with a total of 370 students, located at JL. Dewi Sartika No.71, Central Java. with research subjects for the 2018/2019 Academic Year students. And the sample in this research is class $2 \mathrm{~A}, 2 \mathrm{~B}$ and $2 \mathrm{C}$ which are divided into 1 (one) class as a sample of the experimental class that is class $2 \mathrm{~A}$, then 1 (one) 2C Control Class and 1 (one) 2B Test Class. The research instrument in this study used data relating to teaching and learning activities during the trial. The instruments include the following: (a) learning device validation sheets consisting of: (1) RPS validation sheets; (2) RPP validation sheets; (3) Handphone Application validation sheets, (b) observation sheets (observation sheets) student problem solving skills.

Before carrying out experiments it is necessary to know the initial conditions of the control class with the experimental class. The data needed to determine this condition uses pre test scores. The data is calculated by testing the normality, homogeneity and average similarity. After the design of the learning kit is made, the learning kit is asked for an evaluation by an expert validator consisting of 3 validators. To find out the increase in student achievement in the classroom with Learning Application aided by Handphone Applications and learning in the class using conventional methods based on the value at the beginning and the value at the end of learning. Then to find out the improvement of problem solving abilities in students using the scores before the test and after the test entered into the Gain Normality value $\langle g\rangle$ obtained and translated according to the Gain Normality criteria $\langle g\rangle$.

\section{Result and Discussion}

\subsection{Expert Validation Results for RPS}

The validator's assessment of the RPS is based on the indicators on the validation sheet, conveying that the RPS is valid and can be used with a little revision. And related to the revision of the validator can be seen in table 1 . 
Table 1. Revised RPS based on validator input

\begin{tabular}{|c|c|c|}
\hline $\begin{array}{l}\text { The revised } \\
\text { one }\end{array}$ & Before Revision & After the Revision \\
\hline Assessment & $\begin{array}{l}\text { Assessment of } \\
\text { problem solving } \\
\text { skills is only } \\
\text { assessed by } \\
\text { observation } \\
\text { sheets. }\end{array}$ & $\begin{array}{l}\text { Assessment of } \\
\text { problem solving } \\
\text { skills using } \\
\text { observation sheets } \\
\text { and the process of } \\
\text { students solving } \\
\text { problems. }\end{array}$ \\
\hline $\begin{array}{l}\text { Character } \\
\text { Value }\end{array}$ & $\begin{array}{l}\text { Character values } \\
\text { that will be the } \\
\text { focus of research } \\
\text { have not been } \\
\text { raised. }\end{array}$ & $\begin{array}{l}\text { The independence } \\
\text { indicator } \\
\text { character is } \\
\text { raised. }\end{array}$ \\
\hline Indicator & $\begin{array}{l}\text { Indicators of } \\
\text { achievement of } \\
\text { competencies } \\
\text { made are not yet } \\
\text { detailed. }\end{array}$ & $\begin{array}{l}\text { Indicators of } \\
\text { competency } \\
\text { achievement } \\
\text { include indicators } \\
\text { of independence } \\
\text { of attitude, } \\
\text { indicators of } \\
\text { problem solving } \\
\text { skills and } \\
\text { indicators of the } \\
\text { ability to solve } \\
\text { applied } \\
\text { mathematics } \\
\text { problems } 2 .\end{array}$ \\
\hline
\end{tabular}

\subsection{Expert Validation Results for RPP}

Revisions to the lesson plan include revisions to sections directly related to learning activities, evaluation tools, characters, and indicators. A more complete explanation about the revised RPP can be seen in table 2.

Table 2. Revised RPS based on validator input

\begin{tabular}{|c|c|c|}
\hline $\begin{array}{l}\text { The revised } \\
\text { one }\end{array}$ & Before Revision & $\begin{array}{l}\text { After the } \\
\text { Revision }\end{array}$ \\
\hline $\begin{array}{l}\text { Learning } \\
\text { objectives }\end{array}$ & $\begin{array}{l}\text { Learning } \\
\text { objectives are still } \\
\text { globally not yet } \\
\text { detailed for each } \\
\text { meeting }\end{array}$ & $\begin{array}{l}\text { Learning } \\
\text { objectives have } \\
\text { been detailed for } \\
\text { each meeting. }\end{array}$ \\
\hline Indicator & $\begin{array}{l}\text { Indicators of } \\
\text { independence } \\
\text { character have not } \\
\text { yet appeared in } \\
\text { learning }\end{array}$ & $\begin{array}{l}\text { Indicators of } \\
\text { independence } \\
\text { character have } \\
\text { appeared at each } \\
\text { stage of learning }\end{array}$ \\
\hline $\begin{array}{l}\text { Learning } \\
\text { Activities }\end{array}$ & $\begin{array}{l}\text { Stages of learning } \\
\text { activities have not } \\
\text { been so apparent }\end{array}$ & $\begin{array}{l}\text { Stages of } \\
\text { activity are } \\
\text { already visible }\end{array}$ \\
\hline Assessment & $\begin{array}{l}\text { In the test } \\
\text { questions there are }\end{array}$ & $\begin{array}{l}\text { The test } \\
\text { questions }\end{array}$ \\
\hline
\end{tabular}

\begin{tabular}{lll}
\hline $\begin{array}{l}\text { The revised } \\
\text { one }\end{array}$ & Before Revision & $\begin{array}{l}\text { After the } \\
\text { Revision }\end{array}$ \\
\hline & no answer keys & $\begin{array}{l}\text { already have } \\
\text { and scoring } \\
\text { guidelines }\end{array}$ \\
& $\begin{array}{l}\text { answer keys and } \\
\text { scoring }\end{array}$ \\
\hline
\end{tabular}

\subsection{Expert Validation Results on the Handphone Application}

The revision of the Handphone Application includes a revision of the section that is directly related to the item, appearance and variation of the questions. A more complete explanation of the revision of the Handphone Application is contained in table 3 as follows:

Table 3. Revised Handphone Application based on validator input

\begin{tabular}{|c|c|c|}
\hline $\begin{array}{l}\text { The revised } \\
\text { one }\end{array}$ & $\begin{array}{l}\text { Before } \\
\text { Revision }\end{array}$ & $\begin{array}{l}\text { After the } \\
\text { Revision }\end{array}$ \\
\hline \multirow[t]{2}{*}{ The questions } & $\begin{array}{l}\text { Graded } \\
\text { questions need } \\
\text { to be added }\end{array}$ & $\begin{array}{l}\text { There have been } \\
\text { additional } \\
\text { graded } \\
\text { questions }\end{array}$ \\
\hline & $\begin{array}{l}\text { Enrichment and } \\
\text { challenge issues } \\
\text { need to be } \\
\text { added }\end{array}$ & $\begin{array}{l}\text { Already there } \\
\text { are questions } \\
\text { about } \\
\text { enrichment and } \\
\text { challenges }\end{array}$ \\
\hline $\begin{array}{l}\text { The truth of the } \\
\text { concept }\end{array}$ & $\begin{array}{l}\text { There are still } \\
\text { some wrong } \\
\text { concepts }\end{array}$ & $\begin{array}{l}\text { It has been fixed } \\
\text { based on } \\
\text { validator input }\end{array}$ \\
\hline Picture & $\begin{array}{l}\text { Image / photo } \\
\text { source not } \\
\text { included }\end{array}$ & $\begin{array}{l}\text { Image / photo } \\
\text { source included }\end{array}$ \\
\hline $\begin{array}{l}\text { Room for } \\
\text { problem solving }\end{array}$ & $\begin{array}{l}\text { There is no } \\
\text { room to solve } \\
\text { the problem }\end{array}$ & $\begin{array}{l}\text { A place has } \\
\text { been added for } \\
\text { students to work } \\
\text { on problems }\end{array}$ \\
\hline $\begin{array}{l}\text { Guidelines for } \\
\text { working on }\end{array}$ & $\begin{array}{l}\text { Need to be } \\
\text { given guidance } \\
\text { for students to } \\
\text { work on }\end{array}$ & $\begin{array}{l}\text { Guidance has } \\
\text { been added to } \\
\text { do it }\end{array}$ \\
\hline Display & $\begin{array}{l}\text { Needs to be } \\
\text { improved to } \\
\text { appear more } \\
\text { attractive }\end{array}$ & $\begin{array}{l}\text { Display has } \\
\text { been changed }\end{array}$ \\
\hline
\end{tabular}

In the assessment of the Handphone Application it can be concluded that the majority stated that the Handphone Application is easy to understand, interesting, can help understanding concepts, and can foster student independence. Meanwhile, two lecturers as observers also commented that the Handphone application provides positive support for student learning activities and provides support for understanding the concept of the material. Observers 
also considered that the Handphone Application could be used by students to learn independently easily.

In the assessment of learning models assisted by the Handphone Application that most students stated that the learning process made them more receptive to concepts, and understood the subject matter well. Overall the average value of the student response questionnaire was 4.19 with a maximum value of 5 , so the student response was positive.

The final product of this research development is in the form of learning tools, namely: RPS, Learning Implementation Plan (RPP), Handphone Application. On devices developed using the Handphone application and other devices such as RPS and RPP. During the manufacturing process a revision was made in accordance with the input of the parties related to the trial process so that the final prototype was obtained.

Based on the results of the five validators, the average value of the RPS device is 3.40 and the validator generally states that the RPS is very valid so that it can be used with a little improvement. According to the validator in the RPS that is studied, it is important to note that indicators must describe the objectives or competencies to be achieved, learning activities must show the stages of learning activities with the help of the Handphone Application.

RPS is expected to be in line with the implementation of the RPP. The validator's general assessment and revision of the RPS for the implementation of the development of learning tools are more emphasized in the elaboration of learning activities and assessment characteristics. Learning activities adapted to learning with the help of the Handphone Application. While the assessment characteristics are adjusted with regard to the achievement of student competencies, because the assessment has meaningful information to see the completeness of learning outcomes. Both issues regarding the revision need to be given more attention relating to the smooth running of research trials. On the RPP Tool Based on the validation of the five validators obtained the average value of the lesson plan lesson 3.26. According to the validator an important point in RPP is the Indicator and learning objectives must be in accordance with the objectives of developing learning devices, learning activities must be in accordance with learning with the help of the Handphone Application.

In the Handphone Application which is an important point of learning tools developed in research is an application that facilitates the learning activities process that contains subject matter, examples, science activities both the learning process in the classroom or outside the classroom and this application includes the cultivation of the character of independence. Based on the validation of the five validators obtained an average value of the learning device 3.30. In general, the validator states that the Handphone Application is valid so that it can be used with a slight improvement. The validator's evaluation of the student's textbook learning tool is seen from the indicators contained in the Handphone Application. Some important points to consider are making the program link more operational environment, writing mathematical symbols using the equation editor, pictures contained in the Handphone Application are referred to. In preparing the Handphone Application, it must also be adapted to the learning approach used, namely learning with the help of the Handphone Application and the Handphone Application, which is expected to further instill the character of independence and provide convenience for students, especially in improving achievement in applied mathematics courses 2 .

Practicality Test Results of learning devices with the help of the Handphone Application, before being directly tested on treated classes, first a limited class trial is conducted, the results obtained in the form of data observing the ability of lecturers and student responses to get practicality data. From the results of the analysis of the data obtained shows the ability of lecturers to manage the class well and student responses are also classified. This shows that the learning device developed can be directly tested on a trial class. Good and positive results obtained from observations of the ability of lecturers and student response questionnaires show that the developed devices have fulfilled practical criteria.

Discussion on Effectiveness Test on the device before being tested for effectiveness, testing was previously carried out as a prerequisite to test whether the class that received the treatment and the class that did not receive the previous treatment was declared homogeneous and fulfilled the normality test. Based on the results of calculations from the acquisition of the value of applied mathematics 2 before learning it can be concluded that the data are normally distributed and the variance of both homogeneous classes.

Due Diligence Test results with the prerequisite test on the acquisition data of the final applied mathematics score 2 after learning with the help of the Handphone Application. The prerequisite tests meet the 
homogeneous variants and have normal distribution. Then an individual completeness test is performed, with an average test of two parties. Individual completeness results are given complete due treatment individually. Likewise for classical completeness, from the calculations it is concluded that students complete classically.

Then the success of the development of learning tools with the help of the Handphone Application consisting of RPS, RPP, Handphone Application was developed in a gradual arrangement both in terms of material and the delivery of examples of questions and exercises provided from simple to complex stages, a clear depiction of character values implanted so that student achievements can be built properly.

The influence test is carried out with the help of SPSS namely regression test. Simple regression test results on the character of independence of the ability to solve the problem shows that the character of independence affects student achievement. The next simple regression test also shows that problem solving skills affect students' problem solving abilities. A multiple regression test was carried out showing that skills and independence together affected the ability of students. So that shows that both of them have a good (positive) influence on the ability to solve student problems. The ICT learning model has a strategy created by lecturers ranging from preliminary, core and closing activities, but also to learning material and learning resources (Jones, P., et al., 2014).

Furthermore, an increase test was performed showing the average end of semester exam scores after participating in learning with the help of the Handphone Application is more than the average improvement after following conventional model learning. The ICT learning process has four characteristics including: emphasizing the learning process rather than teaching, education has a flexible structure, has independent characteristics, and education has a process that is environmentally sustainable (Purbasari, et al, 2013). The effect of Handphone Application-assisted learning on Electronic Engineering Study Program students, and these results conclude that the use of two-fold learning innovations is more effective than conventional learning (Yadav, A., et al, 2011). The implications of the ICT skills of teachers have the potential to influence learning outcomes (Fitriyadi, H., 2013).

The process of learning device innovation has gone through the stages of validation, revision, field trials on students, until finally a valid draft is obtained.
Furthermore, the learning tools after going through the trial process have also given results, namely: (1) Final Score of students achieving completeness classically or individually, (2) there is a positive influence on the attitude of independence variable on student achievement, (3) the average value of the Final Semester Exams get better treatment than the average class that is not treated (4) there is an increase in students' laziness solving abilities. Based on the achievement of the four criteria, the innovation of learning devices with the help of the Handphone Application has resulted in an effective learning process.

\section{Conclusion}

Using the 3-D development model (a modification of 4D) produces an applied mathematics learning device 2 with the help of the Handphone Application, where the device consists of RPS, RPP and Handphone Applications. The learning device innovation has gone through a validation process and is declared valid by people who are experts / experts in their field, so the mathematics learning device developed with the Handphone Application in this study is valid.

The use of applied mathematics learning tools 2 is declared practical, namely:

a. The results of calculations on the learning process with the help of the Handphone Application in particular the results of student responses with the help of the Handphone Application, based on predetermined criteria, it is concluded that the response of students is included in the positive category

b. The results of the calculation of the observation sheet on the management of learning with the Handphone Application, based on established criteria, the conclusion is that the Lecturer is able to manage the class well and is in a very high category.

c. Learning of Applied Mathematics 2 material with the help of Handphone Application is declared effective, namely the ability of student achievement in Applied Mathematics 2 achieves completeness both individually and classically, in other words students who are given learning with the Handphone Application with a value of 70 completed individually. Then based on the classical completeness calculation, it can be concluded that the students meet the classical completeness or the percentage of students who achieve a completion score of more than $75 \%$. 
d. The positive influence of the attitude of the character of independence so that students can improve achievement with the indicator of an increased final exam score in learning mathematics applied 2 .

\section{Acknowledgment}

Thank you to the DPRM Ministry of Technology and Higher Education Research for research funding through the starter dose research scheme (PDP) for the 2019 Budget.

\section{References}

[1] A. A. Shahroom and N. Hussin, 'Industrial Revolution 4.0 and Education', Int. J. Acad. Res. Bus. Soc. Sci., 2018.

[2] A. Aziz Hussin, 'Education 4.0 Made Simple: Ideas For Teaching', Int. J. Educ. Lit. Stud., 2018.

[3] W. Aulbur, A. CJ, and R. Bigghe, 'Skill Development for Industry 4.0', Roland Berger, BRICS Skill Development Working Group, India Section. 2016.

[4] F. Fatimah, 'KEMAMPUAN KOMUNIKASI MATEMATIS DAN PEMECAHAN MASALAH MELALUI PROBLEM BASED-LEARNING', $J$. Penelit. dan Eval. Pendidik., 2013.

[5] E. Hariyati, Mardiyana, and B. Usodo, 'Efektivitas Model Pembelajaran Kooperatif Tipe Team Assisted Individualization (TAI) dan Problem Based Learning (PBL) pada Prestasi Belajar Matematika Ditinjau dari Mulpile Intelligences Siswa SMP Kabupaten Lampung Timur Tahun Pelajaran 2012/2013', J. Elektron. Pembelajaran Mat., vol. 1, no. 7, pp. 721-731, 2013. 